\title{
Exemplary Urban Practitioners in Neighbourhood Renewal: Survival of the Fittest... and the Fitting
}

\author{
Ton van der Pennen ${ }^{1}$ Gerard van Bortel $^{2}$
}

Published online: 6 June 2015

(c) The Author(s) 2015. This article is published with open access at Springerlink.com

\begin{abstract}
Often institutional solutions such as structures and organisations are seen as best practices in neighbourhood renewal. Using empirical case study data from the Netherlands and the UK, this paper demonstrates that there should be more attention for the role of individual urban practitioners. The relevance of this conclusion goes beyond the domain of neighbourhood regeneration alone. Due to the new government policy paradigms (e.g. Big Society/Participation Society), welfare reforms are introduced that combine severe austerity measures with more responsibilities for individual citizens and cross-sectorial partnerships between institutions. This post-crisis participation society calls for individuals that are able to 'make a difference' by bridging the gap between the systems of government agencies and other institutions, and the lifeworld of residents. But what are the characteristics and working methods of highly effective 'exemplary urban practitioners'? This paper explores the characteristics of these practitioners by analysing empirical data from neighbourhood renewal case studies using Habermas system/lifeworld concept.
\end{abstract}

Résumé Les solutions souvent institutionnelles telles que les structures et les organisations sont considérées comme des pratiques exemplaires pour la réhabilitation des quartiers. À l'aide de données d'études de cas empiriques issues des PaysBas et du Royaume-Uni, cet article démontre qu'il conviendrait de prêter davantage d'attention au rôle des différents professionnels urbains. La pertinence de cette conclusion va au-delà du seul domaine de la réhabilitation des quartiers. En raison de nouveaux paradigmes de la politique du gouvernement (p. ex. «Big

Gerard van Bortel

g.a.vanbortel@tudelft.nl

1 OTB Research Department for the Built Environment, Faculty of Architecture and the Built Environment, Delft University of Technology, Delft, The Netherlands

2 Department Real Estate and Housing, Faculty of Architecture and the Built Environment, Delft University of Technology, p.o.Box 5043, 2600 GA Delft, The Netherlands 
Society » ou « Participation Society »), les réformes des aides sociales sont introduites, qui combinent des mesures d'austérité sévère avec plus de responsabilités pour les citoyens et des partenariats intersectoriels entre les institutions. Cette société de participation d'après-crise nécessite des individus capables de "faire bouger les choses » en comblant l'écart entre les systèmes des organismes publics et des autres institutions et le monde vécu des résidents. Mais quelles sont les caractéristiques et les méthodes de travail des «professionnels urbains exemplaires » efficaces ? Cet article explore les caractéristiques de ces professionnels en analysant les données empiriques d'études de cas de réhabilitation de quartiers à l'aide du système Habermas/concept de monde vécu.

Zusammenfassung Oftmals werden institutionelle Lösungen, wie Strukturen und Organisationen, als bewährte Praktiken in der Stadtviertelentwicklung betrachtet. Unter Verwendung von Daten aus empirischen Fallstudien in den Niederlanden und Großbritannien zeigt dieser Beitrag, dass der Rolle einzelner Praktiker in der Städteentwicklung größere Beachtung geschenkt werden sollte. Die Bedeutung dieser Schlussfolgerung geht über den Bereich der Regeneration von Stadtvierteln hinaus. Aufgrund neuer regierungspolitischer Paradigmen (z. B. Big Society/Participation Society) werden Sozialhilfe-Reformen eingeführt, die strenge Sparmaßnahmen mit einer größeren Verantwortung für individuelle Bürger und bereichsübergreifenden Partnerschaften zwischen Institutionen verbinden. Diese Partizipationsgesellschaft nach der Krise erfordert Personen, die „etwas bewegen"können, indem sie die Lücke zwischen den Systemen der Regierungsbehörden bzw. anderer Institutionen und der Lebenswelt der Bürger schließen. Doch was sind die Merkmale und Arbeitsmethoden höchst effektiver ,,beispielhafter Praktiker im Bereich der Städteentwicklung “? In diesem Beitrag werden die Merkmale dieser Praktiker untersucht, indem man empirische Daten aus Fallstudien zur Stadtviertelerneuerung nach dem Habermas-System/Lebenswelt-Konzept analysiert.

Resumen A menudo, las soluciones institucionales tales como las estructuras y las organizaciones son vistas como las mejores prácticas en la renovación de los barrios. Utilizando los datos empíricos de estudios de casos de los Países Bajos y del Reino Unido, el presente documento demuestra que debe prestarse más atención al papel de los profesionales urbanos individuales. La relevancia de esta conclusión va más allá del campo de la sola regeneración de los barrios. Debido a nuevos paradigmas de la política gubernamental (p.ej.: Gran Sociedad/Sociedad Participativa) se introducen reformas de bienestar social que combinan importantes medidas de austeridad con más responsabilidades para los ciudadanos individuales y asociaciones multisectoriales entre instituciones. Esta sociedad participativa posterior a la crisis apela a los individuos que pueden "crear la diferencia" acortando distancias entre los sistemas de las agencias gubernamentales y otras instituciones, y el mundo de la vida de los residentes. Pero ¿cuáles son las características y los métodos de trabajo de los "profesionales urbanos ejemplares" sumamente eficaces? El presente documento explora las características de dichos profesionales mediante el análisis 
de datos empíricos de estudios de casos de renovación de los barrios utilizando el concepto del mundo de la vida/sistema de Habermas.

Keywords Governance - Urban practitioners - Neighbourhood renewal - System · Lifeworld

\section{Introduction}

\section{Making a Difference in Neighbourhood Renewal}

Since the early 2000s, various area-based initiatives have been taken to address issues of concentrated social and economic deprivation and dysfunctional housing markets. In the Netherlands, the government developed the 'Grote Steden Beleid' (Big Cities Policy) (Van Kempen 2000) and in conjunction created several programmes to support deprived neighbourhoods, the most recent initiative being the 2007 'Krachtwijken Aanpak' (Empowered Neighbourhoods Programme) that prioritised the social, economic and physical renewal of 40 neighbourhoods in 18 Dutch cities (Vogelaar 2007). In the UK, the Housing Market Renewal (HMR) Programme (Wilson 2013; Audit Commission 2011) and the New Deal for Communities (CLG 2012; Leather et al. 2012) are examples of area-based approaches.

A recurring issue in many area-based approaches is the mismatch between the ambition of the government, social housing providers to regenerate neighbourhoods and the often disappointing tangible results delivered by these schemes. Although the overall assessment of these neighbourhood renewal programmes was not always positive (Allen 2008; Webb 2010; Lub 2013; SCP 2013), research into how these programmes were delivered 'on the ground' reveal accounts of often very effective individuals (see for example Sieckelinck et al. 2013). Recent results from the 'Best Persons' research project (Van den Brink et al. 2012) ${ }^{1}$ deliver new insights into the characteristics and activities of these exemplary practitioners. But what does it take, as an individual, to make a substantial difference in the regeneration of disadvantaged neighbourhoods? Answering this question is central to this paper, and is of great importance in an era where citizens are expected to become more actively involved in improving their community and exemplary practitioners are needed to bridge the divide between the systems of the state, profit and non-forprofit agencies and the lifeworld of citizens.

Economic and policy drivers lead national governments into retreating from the provision of services and support in the public domain, including neighbourhood renewal. The gap thus created, generates room for civil society initiatives and calls for more active citizenship and a shift from a government-led welfare regime towards a community-led participation society. This opens up new ways for

\footnotetext{
1 The Best Persons research project was a collaborative effort undertaken by Ton van der Pennen from the Delft University of Technology and scholars Tilburg University: Gabriel van den Brink, Laurens de Graaf and Merlijn van Hulst. The research project was commissioned by the NICIS Institute, a scientific knowledge centre for the Dutch cities now part of the Platform31 knowledge centre: www.platform31.nl.
} 
citizens' participation (Van der Pennen 2014). As part of the Localism agenda and Participation Society policy paradigm, national governments in the UK and the Netherlands, respectively, have expeditiously started with the implementation of important elements of their agenda by restructuring welfare state provision. In this profound process of policy decentralisation, local authorities are given more responsibilities in a wide range of domains, such as homelessness, liveability, crime, youth, unemployment, housing, education, health and social care.

The relation between state, civil society organisations and citizens has changed fundamentally. Less state dominance and less financial means ask for new arrangements and mechanisms. Citizens are expected to become more involved in shaping local policies. Citizens' participation moved away from 'talking together' towards 'working together' by mobilisation of resources and co-creation. This 'fourth way' of citizens' involvement (Van der Pennen 2014) entails a transformation from a hierarchical, top-down society to a more horizontal, decentralised, bottom-up society.

Many empowered citizens may be perfectly able to operate in this new post-crisis participation society, but without adequate support vulnerable people and places may fall into the abyss created by government retrenchment and austerity (Tonkens 2014; Blond 2010). The qualities to engage in more co-productive forms of resident participation are often less developed in residents (groups) in disadvantaged neighbourhoods, precisely the place where increased citizens involvement is most desirable. Support from professionals (exemplary practitioners) is indispensable to bridge the gap between the lifeworld of these citizens and the system of state, market and third-sector organisations. It is paramount that this gap is closed and we increase our understanding on the key success factors of citizens and practitioners that are able to cross that divide.

Austerity measures in England and the Netherlands have, in addition to the general realignment of the welfare state, reduced the possibilities of housing associations to support neighbourhood renewal. As part of the 2010 Comprehensive Spending Review, most regeneration grant funding in England was cut, the Housing Market Renewal Programme was terminated (Leather et al. 2012). In the Netherlands, the Empowered Neighbourhoods Programme initiated in 2007 and focused on the regeneration of 40 deprived communities was terminated prematurely in 2011 (Ministry of Housing, Neighbourhoods and Integration 2007). On top of that, the new Dutch regulatory social housing framework embedded in the revised 2015 Housing Act limits the involvement of Dutch housing associations in neighbourhood regeneration. The housing market downturn, the introduction of the Landlord Levy (Priemus 2014) and the stricter legal mandate for neighbourhood renewal activities will very likely force housing associations to increase their collaboration with municipalities, market actors and local communities.

The introduction of the Big Society policy agenda by Cameron in 2009 has triggered a stream of public management publications on the participation of citizens in the provision of public services, often referred to as 'co-production' (Pestoff 2014). Research has demonstrated that engagement of citizens can increase the efficiency and effectiveness of public service delivery, and can increase the affective attachment between citizen and government (Clark et al. 2013; Dunston 
et al. 2009; Osborne 2010a, 2010b; Osborne et al. 2013; Thomas 2012). Pestoff also formulated the need to develop new models and methods to better understand the relation between individual and collective co-production as one of the important research topics (Pestoff 2014, p. 399). This paper wants to contribute to increasing that body of knowledge.

\section{Research Methodology}

This paper combines empirical data from two sources. The first source includes the previously mentioned 'Best Persons' research (Van den Brink et al. 2012). In this research, 50 urban practitioners were observed in their daily activities. These practitioners worked in Dutch neighbourhood renewal areas in the five cities that participated in the investigation: Amsterdam, The Hague, Leeuwarden, Utrecht and Zwolle. In order to capture the interactions of practitioners with other actors and local communities, the 'Best Persons' research used observation and in-depth interviews, a kind of urban ethnography, as research methodology. The first part of that fieldwork entailed a scouting exercise to identify potential exemplary practitioners. A senior member of the research team made a long-list of 1000 candidates in the five case study cities. This overview was reduced to a short-list of 225 candidates. Selection criterion was the extent to which practitioners 'stood out' in peer-referrals, in the sense of having played an important role in neighbourhood renewal activities. Based on interviews with these candidates, 50 practitioners were selected for the second step of the research. These individuals were not only professional in the strict sense; the group also included citizens that were (semi-professionally) active as entrepreneur, volunteer or community activist in their neighbourhood.

After the scouting phase, the 50 practitioners were interviewed by the research team and-with their consent-observed in their daily activities. These 'up-close and personal' observations were combined with in-depth interviews with the practitioners and actors in their local network. Members of the research team asked them about their experiences and observed their interactions with other network actors. The stories of the exemplary practitioners were thus triangulated by verifying their stories with the accounts of other actors and observations by members of the research team. This resulted in a substantial number of detailed interview and observation reports that informed our analyses. A more detailed discussion on this very intensive and inductive research process can be found in Van Hulst et al. (2011, 2012).

The second data source (used in "Towards a Typology of Exemplary Urban Practitioners" section) is an on-going longitudinal study into neighbourhood renewal governance, with a special focus on the role of non-profit housing associations in two neighbourhoods (Lozells, Birmingham in the UK and De Hoogte, Groningen in the Netherlands) (Van Bortel 2009; Mullins and Van Bortel 2010; Van Bortel et al. 2009; Van Bortel and Mullins 2009). As in the 'Best Persons' research, data were collected through in-depth interviews and participant observation. Practitioners were selected based on 'snowballing' reversals by peers (Morgan 2008).

This paper continues in "Exemplary Practitioners as Liaisons Between System and Lifeworld" section by linking the concept of the exemplary urban practitioners 
to the wider debate in housing, urban and governance studies. "Towards a typology of exemplary urban practitione" section constructs the theoretical and methodological framework to study the characteristics of exemplary urban practitioners. Using this framework, "Portraits of Exemplary Practitioners" section portrays four urban practitioners, two from the Netherlands and two from the UK. In "Conclusion" section, we will conclude the paper by linking the characteristics of these urban practitioners to the theoretical framework and the results from the overarching 'Best Persons' research and draw some conclusions on the role of exemplary practitioners in post-crisis society.

\section{Exemplary Practitioners as Liaisons Between System and Lifeworld}

\section{The System Versus Lifeworld Divide}

The leading question in this paper is connected to the notion that neighbourhood regeneration is hampered by the incongruence between public and private sector systems and the lifeworld of residents. This Habermassian concept (Habermas 1981, p: 467) is gaining prominence in policy administration and in policy debates. Several recent publications regard this concept as an essential factor in understanding neighbourhood regeneration, resident participation and community development outcomes (Sieckelinck et al. 2013; Van den Brink et al. 2012; WRR 2012). These authors contend that neighbourhood practitioners are key to the success of neighbourhood renewal, because only people, not institutions, are able to cross the divide between the system and the lifeworld of residents. We will discuss this Habermassian concept in more detail below.

In his seminal work, Theory of Communicative Action (1981) Habermas concluded that two forms of rationality are at work in modern society. Firstly, the end-mean rationality dominant in what Habermas calls the system, and secondly, the communicative rationality that is the cohesive mechanism in the lifeworld (Lebenswelt). The system is an extraordinary collection of disparate systems and subsystems that people have developed in the form of organisations, rules, procedures hierarchies and laws in societal domains such as economics, politics, education, housing, science, government, healthcare, welfare and justice.

In contrast, the lifeworld is the domain of informal personal relations between family members, friends and local communities; a world of values and emotions, but also a domain of social inequalities. Relations in the lifeworld are based on informal communications and story telling (Van den Brink et al. 2012, p: 58). In the past, society consisted almost entirely of lifeworld, but gradually systems began to increase in number and size and started to infiltrate, and dominate the lifeworld. Habermas talks of the "colonization of the lifeworld" (Habermas 1981).

The divide between the system and the lifeworld manifests itself sharply in disadvantaged neighbourhoods. Residents in these areas often have very frequent contacts with system agencies, such as the police, the school, the municipality and assorted welfare agencies, because they are often unemployed, have health issues, their children drop out of school or because they are the perpetrators or victims of 
crime, anti-social behaviour and drugs abuse. Increasingly, the compounded combination of social-lifeworld-problems is seen as the essential problem to solve in deprived urban areas (VromRaad 2007; Van den Brink et al. 2012, pp. 63-68).

Most of the professional work in Western Europe neighbourhood renewal programmes is carried out according to system rules. Many urban professionals find it difficult to engage with the lifeworld of residents in these urban areas and vice versa. In order to be heard, residents are forced to translate their own needs into a systemworld vocabulary, a task for which they are often insufficiently equipped. In addition, residents of disadvantaged neighbourhoods are often socially less active, have less developed support networks and therefore find it more difficult to solve their lifeworld problems than the neighbourhood renewal professionals they engage with.

Several scholars have demonstrated the importance of the personal skills of practitioners for effective neighbourhood interventions (Schön 1983; Healey 1992; Forester 1999). Findings from our field studies (Van den Brink et al. 2012; Van Bortel 2013) support the importance of exemplary urban practitioners that are able to connect the residents' lifeworld with system agencies (see Fig. 1).

The divide between system and lifeworld and the discussion on the merits of exemplary practitioners' is related to the debate on civicness explored in a Voluntas special issue (2009, Vol 20). In the editorial to that special issue Dekker and Everts (2009, p: 218) consider civility as something that is primarily embodied in people's attitudes and behaviour, both private and public. They define civicness as the capacity of institutions, organisations, and procedures to stimulate, reproduce and cultivate civility. Exemplary practitioners can be regarded as individuals having high levels of civility.

In the past decade, we have seen a change in focus in academic and policy discourse. There is less emphasise on the efficiency of institutional and management arrangements, but more attention for role and effectiveness of frontline professionals (Van der Lans 2012; Van den Brink et al. 2012; VROMRaad 2007; Van der Pennen and Van Bortel 2013; Tonkens 2014; Tonkens and De Wilde 2013; Stienen 2015).

\section{Towards a Typology of Exemplary Urban Practitioners}

Various researchers have shown a keen awareness of the increasing societal and administrative complexity and explored how practitioners address these complexities based on the idea that what happens in practice is not the result of what

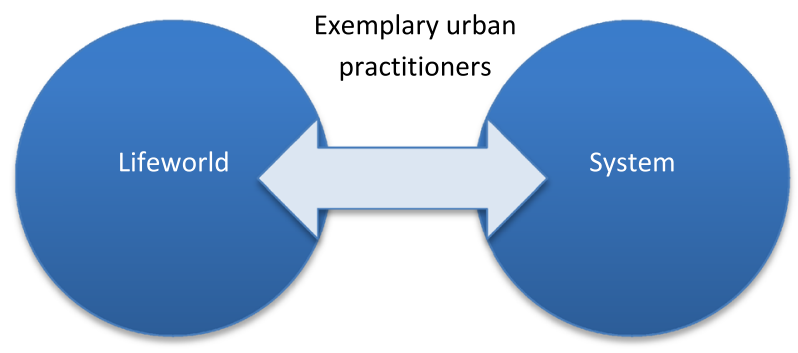

Fig. 1 Bridging the Lifeworld/System divide 
agencies decide, but what individuals achieve (e.g. Schön 1983, Healey 1992, Forester 1999, Lipsky 1980). Van den Brink et al. (2012) theoretically and empirically explored the question 'who are the professionals that make a difference in neighbourhood regeneration?'. Their theoretical exploration included eight different types of practitioners identified in literature (Table 1). Based on these eight characters, Brink et al. (2012, p. 150) constructed an aggregated typology of an exemplary practitioner using generic skills they encountered in literature. Their typology combined skills on two dimensions: entrepreneurship and social engagement. Skills that are hard to combine, because each dimension is characterised by a subjective and an objective element. The subjective element on the entrepreneurial dimension is the capacity to be inspirational. This is characterised by capabilities such as leadership skills, a clear vision, having an open eye for opportunities and a low level of risk averseness. On the other side of the

Table 1 Eight types of urban practitioners

\begin{tabular}{|c|c|c|}
\hline $\begin{array}{l}\text { Practitioner type } \\
\text { (Supporting literature) }\end{array}$ & Mode of operating & $\begin{array}{l}\text { Mode of addressing } \\
\text { incongruities between system } \\
\text { and lifeworld }\end{array}$ \\
\hline
\end{tabular}

1. Reflective professional (Schön 1983, 1987)

2. Deliberate professional (Forester 1999)

3. Street-level bureaucrat (Lipsky 1980)

4. Frontline worker

(Maynard-Moody and Musheno 2003; Durose 2007, 2009, 2011; Tops and Hartman 2009)

5. Everyday maker

(Bang and Sørensen 1999; Bang 2005)

6. Everyday fixer

(Hendriks and Tops 2005)

7. Entrepreneur (political, policy, social, civic, institutional)

(Dahl [1961] 2005; Kingdon 1984; Leadbeater and Goss 1998)

8. Boundary Spanner

(Steadman 1992; Williams 2002)
Reflection-in-action. Experimenting. Learning by doing

Listening. Getting acquitted with people and their problems

Developing routines. Working with labels, routines and simplifications

Engaging with citizens that are deemed worthy

Working independently. Collaborating with experts tactfully and respectfully

As Everyday maker complemented with networking and long-term commitment

Identifying and using resources

Connecting problems, solutions and decisionmakers

Operating between organisations. Facilitating interactions
Experimenting with tensions between wishes and possibilities in a safe environment

Using elements from the lifeworld to enrich or recalibrate the lifeworld

Adapting the lifeworld to fit into the system

Adopting a posture that conforms with the lifeworld

Ignoring the system. Focusing on projects and goals in the immediate vicinity

Focusing on projects and goals and overrule the system

Focusing on actions within the system or within the lifeworld

Connecting system with lifeworld

Source: Van den Brink et al. 2012, p:80-81, abridged version 
entrepreneurial dimension is a strong result orientation; a drive to get things done that is not easily blocked by bureaucratic 'red tape'.

Social engagement, the second dimension, is characterised by networking skills on the objective side of the spectrum, resulting in wide access to actors involved in the local neighbourhood renewal network. This enables practitioners to connect multiple initiatives and policy domains. Empathy is located on the subjective side of the social engagement dimension. It enables exemplary practitioners to build long lasting and robust personal relations with individuals and groups in the local community, and agencies in the local neighbourhood renewal network.

Van den Brink et al. (2012) found that exemplary practitioners are able to move around on the entrepreneurship and social engagement dimensions, simultaneously adopting a style that matches the personality of the practitioners and the specific situation at hand. This results in four types of exemplary practitioners: frontline worker, everyday fixer, social entrepreneur and boundary spanner, each with a distinctive combination of objective and subjective entrepreneurial and social engagement skills. We will discuss these types in more detail below.

\section{Frontline Worker}

The roots of frontline workers are within system agencies. They often work for the local authority, housing associations, third-sector (welfare) organisations or the police. Empathy and direct communication with residents are key to their way of operation. Frontline workers are excellent networkers and stay connected with actors in the system to support residents entangled in bureaucratic procedures. Whereas Lipsky (1980) talked about street-level bureaucrats, nowadays the concept of frontline workers is used to refer to people in similar positions. With specific reference to Dutch frontline workers, Tops and Hartman (2009, see Durose 2009, 2011 for a British case) argue that successful frontline workers possess particular characteristics and skills. They are able to 'read situations' and have a thorough knowledge of the actors involved and their personal backgrounds. In addition, frontline workers have a keen eye for the opportunities that a situation offers. Frontline workers can improvise appropriate ways to act on the spot, a quality that might also be related to what Schön (1983) called 'reflection-in-action'. Finally, successful frontline workers are deeply engaged in what they do, performing their job with heart and soul. Maynard-Moody and Musheno (2003) found that once a frontline worker judged someone as 'worthy', they would go the extra mile to help that person. Going the extra mile might include persuading bosses, bending rules or even using one's personal resources.

\section{Everyday Fixer}

The everyday fixer (Hendriks and Tops 2005; Van de Wijdeven and Hendriks 2009) can be linked back to the character identified by Bang and Sørensen (1999): the everyday maker. These individuals are highly autonomous and active individuals with a strong focus on the here and now. They prefer a pragmatic to an ideological approach. A decisive factor is the enthusiasm and the can-do attitude with which they approach the challenges in disadvantaged neighbourhoods. Residents with 
these characteristics have high levels of self-confidence and engage easily with public and private sector professionals. They do so as partners, not as opponents. The everyday fixer is rather avers to rules and procedures. These individuals are often better versed in starting than in finalising a project. Because of these character traits, their collaboration with professionals is often not very smooth. Their actions, however, often have a profound and positive impact on neighbourhoods and everyday fixers often have an excellent relationship with their local community.

\section{Social Entrepreneur}

Exemplary urban practitioners have entrepreneurial ways of working. They easily start a new project or give a project that was not successful a second chance. In contrast to frontline workers, social entrepreneurs ${ }^{2}$ are less often part of system agencies such as the government or third-sector organisations. They have strong network links with these agencies, but are primarily active in the lifeworld: their neighbourhood and local communities. They often work with their own resources or resources acquired through their network. Subsidies are not the main source for their activities. Similar to frontline workers, social entrepreneurs are pragmatists in dealing with procedures and other system phenomena.

Social entrepreneurs excel at deconstructing and analysing problems into manageable parts. They have a keen eye for recognising opportunities, are team builders and set the example by venturing into unexplored domains (Mintrom and Norman 2009). They can transform local communities by opening up possibilities for self-development. Social entrepreneurs typically start an initiative around a specific policy problem or a societal group with a particular profile, and are able to gather the resources necessary to sustain or even expand that initiative (Korosec and Berman 2006). Social entrepreneurs try to understand social reality from the perspective of citizens. They formulate issues not as problems but as challenges and solving them is a constant drive that makes them 'tick'. Their everyday focus is characterised by getting things done. This focus should not be confused with short-term pragmatism but is also connected to the strategy of entrepreneurs to build and sustain confidence and trust as a foundation for future action and collaboration.

\section{Boundary Spanner}

Boundary spanners are able to make connections with other actors and institutions in other domains, and by doing so create multi-actor networks (Steadman 1992). Boundary spanners often work in positions between two or more systems (e.g. the juridical system and the health system), or between different organisations (e.g. municipality and housing association). They are able to operate in both the system and the lifeworld. Boundary spanners are proficient in both street slang and town

\footnotetext{
${ }^{2}$ With the term 'social entrepreneurs', we refer to individuals with a leading position in social enterprises. We are aware that definitions of social enterprise vary considerably between countries. For a more elaborate discussion on social enterprise in an urban and housing context, we refer to the 2012 Housing Studies special issue on hybridity and Social Enterprise in Housing Organisations.
} 
hall jargon. Boundary spanners are characterised by 'their ability to engage with others and deploy effective relational and interpersonal competencies' (Williams 2002 , p. 110). They might be summoned when a conflict arises between groups of actors. Active listening and empathising are skills of boundary spanners that are crucial to deal with these conflicts (Williams 2002). In contrast to the everyday fixers that have many, but rather weak connections with others, the boundary spanners often have less numerous but stronger connections.

\section{Portraits of Exemplary Practitioners ${ }^{3}$}

From the combined set of empirical data, four portraits of 'exemplary practitioners' will be presented in this paper, two from the city of The Hague in the Netherlands (Hans and Sabrina ${ }^{4}$ ) and two from Birmingham in the UK (Saeed and Jo). This selection can be seen as an illustration of the practice and potential of exemplary practitioners.

\section{Hans: An Everyday Fixer (The Hague, The Netherlands)}

Hans is a police officer working in the Escamp neighbourhood in The Hague, a predominantly early post-WO II area with many low-income residents. Half of the population is of non-western descent; many have a Moroccan or Turkish background. Escamp offers its residents a support network within their local community, but is also an area with social tensions. On several locations in the neighbourhood, young people have been involved in acts of crime and anti-social behaviour. To address these problems, Hans has developed the 'Role Models' project. As part of this project, selected youths collaborate with police officers and youth workers to keep their neighbourhood clean, safe and free of vandalism. These role models confront their peers if they misbehave.

It is part of Hans' strategy to actively engage with youth people that are threatening public order. Hans: "This means that sometimes you have to drop by, talk informally with them 'over a cup of coffee'. Also at night. They live at night." $\mathrm{He}$ is casting his 'actors' like a movie director. Hans' role models come from the mosque, the Moroccan cultural club or the local soccer team.

Hans' mode of intervening is known as the 'community police officer model'. In this model, the police is present in the neighbourhood on a daily basis and keeps close contacts with members of the local community, such as residents, entrepreneurs, shopkeepers and teachers. This strategy to maintain safety in public space is characterised by listening and entering into a genuine and sometimes frank dialogue with the local community. "I take no detours, but go straight to the heart of the matter. Just go and really listen to what the problem is", that is essential

\footnotetext{
${ }^{3}$ Eva Bosch (Delft University of Technology) was involved in the fieldwork of the research project that is a source for this paper and delivered an excellent job in the construction of the portraits of Hans and Sabrina.

${ }^{4}$ On the http://www.bestpersons.eu website you will find filmed portraits of Hans and Sabrina. The website is in Dutch but the portraits have English subtitles.
} 
according to Hans. Hans describes these community police officers as passionate 'cops', "not the 'nine to five' type". Cops have intimate knowledge about the everyday reality of the street, maintain close contacts with the community and understand their language. Many young people in the area see the police as a repressive institution. Through the Role Models Project and community dialogues, this distrust is broken down and young people can be approached more easily. The community police officers liaise between the system's laws, rules and policies and the lifeworld of young people.

In order to improve the quality of the public domain, Hans calls upon citizens to engage in neighbourhood activities together with the police. Collaboratively, they engage with known anti-social behaviour offenders and offer them alternatives for their behaviour. Hans: "The police can act, but it always acts by repression: by arresting or fining people (...) The only way in which it will work in the neighbourhood is by doing it together with residents".

\section{Qualities}

The success of the Role Models project is related to Hans' personal qualities. His focus on action and a solution-oriented approach to neighbourhood problem make him a genuine everyday fixer. However, he also has the networking capabilities to form appropriate working coalitions. His project was not always understood and appreciated by his colleagues within the police force. He had to struggle to get the project started, but like a social entrepreneur, Hans managed to put together his Role Models project. It is a 'police project' but it does not bear the dominant culture of that organisation. In that respect, Hans is also a boundary spanner because for his Role Models project he transferred proven social work approaches to the domain of the community policing.

\section{Sabrina: A Social Entrepreneur (The Hague, The Netherlands)}

Sabrina, a trained artist, was fascinated by the impact of the urban renewal activities in Transvaalwijk, a neighbourhood in The Hague. She wanted to explore how the massive housing demolition affected everyday life in the area. To study these effects from the perspective of the arts, her professional background, she set up a project called 'OpTrek', which has since drawn quite a bit of attention (Lindemann and Schutten 2010; Hekking et al. 2010). OpTrek used buildings slated for demolition as a bridgehead, workspace and meeting place. As an 'urban curator', she inserted art into the fabric of this deprived neighbourhood in order to intervene, investigate, sound out, document and give commentary.

In collaboration with many parties (e.g. neighbourhood residents, government agencies, housing associations and architects), she created art projects and organised debates, and symposiums to discuss opportunities for neighbourhood change. In order to create a playing field for new ideas and to stimulate new initiatives, OpTrek took temporarily possession of demolition sites and vacant premises in the area. One of these initiatives was 'Hotel Transvaal' (Hekking et al. 2010) opened in 2007. For a year and a half, the hotel used vacant premises in the area. Artists converted them 
into themed hotel rooms. Instead of being concentrated in a single building, the hotel rooms were located throughout the Transvaalwijk. The guests had to frequent local businesses for breakfast and dinner. The numerous services already available in Transvaal-restaurants, hairdressers, bakeries-thus served as the hotel's amenities. In a highly accessible and effective manner, the hotel facilitated the convergence of diverse cultures, making it a congenial place to stay. It engendered a hospitable setting in a neighbourhood that the media usually depicted in negative terms.

\section{Qualities}

What makes Sabrina's approach so striking is a certain fearlessness and daring. She was the driver, the powerhouse, of her team. Buildings were refitted in ways not always in line with building regulations. By managing a real hotel, a responsibility she had little experience with, Sabrina jumped in at the deep end- "just do it". Her persistent and daring character seems to merge with her enthusiasm and dedication to her organisation. The fact that OpTrek, which began as a three-year project, eventually operated for 8 years testifies to her commitment.

Sabrina regards herself also as a networker. She was able to create a network for her organisation that circumvented the established policy structure. She created a refuge, a place of freedom in the fullest sense of the word: free of conventions, expectations, deeply ingrained roles, procedures and regulation, stereotypes and prejudice (see Haffmans 2006). Much of her work came down to networking and mobilising support for her initiatives. Her main partners in that effort were the residents (as audience and sometimes as participants in the art projects), the municipality and the housing association (as audience, for consultation, and for financing), various funding bodies and other artists and professionals in the field of urban renewal (for their knowledge and creativity).

\section{Saeed: A Boundary Spanner (Birmingham, the United Kingdom)}

Saeed is the son of an Imam who emigrated from Bangladesh to the UK in the 1980s. Saeed lives in Lozells, an area not far from the Birmingham city centre. The area is a lively community with a predominantly black minority ethnic population originating from places such as Bangladesh, Pakistan and the West Indies. The area has always been a welcome place for new immigrants, but is also challenged by a concentration of social and economic problems; low incomes, high levels of unemployment, low educational attainment and high crime rates. Saeed worked for the National Health Service (NHS) as a Public and Patient Involvement officer and Engagement Manager, and combined this with his work as a community activist in Lozells. As co-chair of the Lozells Neighbourhood Forum, he was closely involved in organising the community. He was able to liaise with local authority officers and representatives of third-sector organisation, such as housing associations. He was a Community Board Member for Urban Living, the organisation responsible for Housing Market Renewal pathfinder for North West Birmingham (and neighbouring Sandwell). In 2010, Saeed received the Lozells Community Volunteer of the Year 
award. Saeed left his job at the NHS and started as full-time community organiser for Citizens UK, a well-known civil society organisation.

Saeed is one of the co-founders of Aspire and Succeed, a social enterprise set up by five Lozells residents with strong credentials in teaching, youth and community work. Aspire and Succeed is a charitable company that aims to increase the educational achievements in order to support the upward social mobility of residents. The work of Aspire and Succeed is aimed at helping residents, especially young people, to finding rewarding work. The organisation does this by mentoring students to manage their own learning, maximise their potential and develop their skills and self-confidence. As part of their ambition to build stronger community aspirations, Aspire and Succeed organises awards to celebrate the achievements and efforts of pupils and their families.

\section{Qualities}

Saeed is known for his eloquent, but challenging, way of scrutinising the performance of public sector organisations such as housing associations, the Birmingham City Council and other statutory bodies. According to Saeed, not enough use is made of the talents of residents and organisations should involve residents more in the development of plans. Danielle Corfield, Detective Chief Inspector at West Midlands Police described Saeed as " $a$ 'true community leader' and a driving force within the Lozells community, passionate, challenging and often a voice of reason". Former NHS colleague Aftab Rahman described Saeed as "one of the most credible young leaders to emerge in Birmingham. He is a grass roots campaigner and will challenge agencies to deliver the best services for the community. On a professional level, he is highly regarded by his colleagues and the community alike for his contributions for connecting the NHS to the community".

Saeed's way of working closely resembles the characteristics of a boundary spanner. He tries to connect the lifeworld of the community with system agencies, but his roots are in the lifeworld. Saeed and the activities of Aspire and Succeed also resemble the social entrepreneur and everyday fixer types.

\section{Jo: A Frontline Worker (Birmingham, the United Kingdom)}

Jo is a Regeneration Project Officer working for housing association Midland Heart, one of the largest social landlords in the UK. Jo works in the North West area of Birmingham. She came into post in late 2010, not long after the UK Libdem coalition government had presented its Comprehensive Spending Review containing unprecedented austerity measures. Budgets for neighbourhood regeneration were abolished or significantly reduced. Jo did not have any projects or budgets to offer. Her boss told her "your remit is 'you don't have a project, you don't have a budget. Your project is be around, see what's happening [in the neighbourhood] and seek to support that",'". As a frontline regeneration officer, Jo often was the liaison between the neighbourhood and Midland Heart's housing management officers that serviced a wider geographical area. 
Jo was very sceptical of the old way of working, where the housing association, or the local authority, would come into an area and promise "the world", but were often not able to deliver on their promises. She is far more positive about working very closely with residents and the freedom and support Midland Heart gives her to drive ideas forward, see what is happening on the ground and find the places where she can give support. This new way of working generates a lot of energy, Jo said.

Midland Heart officers like Jo are meeting more people then previously in the era of state-funded regeneration projects. Now real relationships are built with residents. Implementing ideas for the neighbourhood does not necessarily involve large amounts of money. Jo: "Projects are not driven by money, but powered by passion." When Jo started working for Midland Heart, by the end of 2010, people asked her "You got any money? You got any grants, going?" She had to admit "nah, I haven't got anything like that" and in a way Midland Heart had to prove its worth from scratch.

\section{Qualities}

Jo wants to be as useful as possible for the areas she works for, and that means being visible and approachable for residents. With her background in the management of small charities and fund-raising, Jo is able to help secure resources to support neighbourhood initiatives. As a frontline worker, she has a keen eye for community members that are less actively engaged in neighbourhood regeneration activities.

A local councillor and former Lozells Neighbourhood Forum chair said about Jo: "(...) she is very energetic, very involved and really good in community engagement. She comes out in the weekends, is very hands-on, she takes initiative and is well supported by her management. Everybody praises Midland Heart because they're really active". In an Inside Housing interview ${ }^{5}$, a local community organiser said that "Jo works on grass-roots level, she is in contact on a day-to-day basis. I probably work with he more than some of her colleagues back at the office. She is a great example of how housing professionals are working with members of local communities".

Recently Jo has moved into a less geographically focused position within the Midland Heart organisation. She is now involved in projects focused on specific target groups dealing with topics such as financial inclusion (e.g. tackling rent arrears and preventing evictions) and employment schemes. This illustrates the challenge to keep exemplary practitioners connected to local communities. Exemplary frontline workers are a valuable asset to their organisation, and it is only natural that they seek, or are offered, new challenging projects and assignments. This also illustrates that system actors involved in neighbourhood regeneration should develop strategies to secure adequate staff numbers of exemplary frontline workers.

\footnotetext{
5 Inside Housing Interview 10-02-2012. www.insidehousing.co.uk.
} 
Table 2 Connection between portrayed practitioners and exemplary practitioner's characteristics

\begin{tabular}{llllll}
\hline & \multicolumn{2}{l}{ The Netherlands } & & & \multicolumn{2}{l}{ United Kingdom } \\
\cline { 2 - 3 } & Hans & Sabrina & & Saeed & Jo \\
\hline Frontline worker & $\mathrm{v}$ & $\mathrm{V}$ & & $\mathrm{V}$ \\
Everyday fixer & $\mathrm{V}$ & $\mathrm{v}$ & & $\mathrm{v}$ & $\mathrm{v}$ \\
Social entrepreneur & $\mathrm{V}$ & $\mathrm{V}$ & & $\mathrm{v}$ & $\mathrm{v}$ \\
Boundary spanner & & $\mathrm{v}$ & & $\mathrm{V}$ & \\
\hline
\end{tabular}

$V=$ dominant characteristic, $v=$ secondary characteristics

\section{Conclusion}

In this concluding section, we will link the characteristics of the four practitioners portrayed in this paper with the four generic types of exemplary practitioners distinguished in "Towards a Typology of Exemplary Urban Practitioners" section. Please note that this link is not exclusionary. As we will point out, our practitioners often combine the characteristics of one dominant type of exemplary practitioner with the character traits of other types. Table 2 provides and overview of the connections between the generic types and the portrayed practitioners.

All portrayed exemplary practitioners combine an intrinsic drive to pursue their ideals and vision with an urge to achieve results. When found in exemplary urban practitioners, social entrepreneurship emerges in the ambition to discover how things work and can be improved. Like Sabrina, with her Transvaal Hotel, boundary spanner Saeed and frontline worker Jo have also characteristics of a social entrepreneur. Saeed not only co-founded a social enterprise to support young people in his neighbourhood, he is also very focused on results. This is visible in his work as a community organiser, but also in this ability to scrutinise organisations such as housing associations if results remain wanting. He does this without damaging the relationships he has developed with these agencies. Sabrina is, in addition to her characteristics as a social entrepreneur, also an active boundary spanning networker and able to secure favourable conditions for her Transvaal Hotel.

Exemplary urban practitioners are natural networkers, as is illustrated in the portraits in "Portraits of Exemplary Practitioners" section. They need to be, because they cannot do their work in isolation. Their work itself is about social interactions, they collaborate with many actors when trying to mediate between people, policies and organisations. In addition, they often need others to complement them in the more technical, administrative and organisational aspects of their work. In order to be successful, exemplary practitioners need to have strong supporters in the system (Hendriks and Tops 2005).

\section{Holistic Problem Orientation}

Exemplary urban practitioners show high levels of empathy in their frequent (everyday) interactions with other professionals and residents. Through these 
interactions, they gain valuable local knowledge, which is essential to their work. The contacts practitioners have with the local community help them to develop their own local network. Policy officer Hans' local knowledge, for example, is gained not only by observing youngsters at street corners, but also by talking with them. His working hours are not from 9 to 5, but are determined by the street-life schedule of the boys. We saw the same strategy in the portraits of Saeed and Jo. By gathering knowledge in this way, they not only learn about the various and interrelated problems that citizens are confronted with from the perspective of the citizens themselves, but also increase their knowledge of strategies citizens use to tackle problems and about their capacities to do so.

In the system, support services are fragmented over different agencies, professions and specialities. In the lifeworld of residents, problems and people are complex and interrelated. By empathically looking at the 'whole' problem of residents and their capacities to contribute to a solution, the urban practitioners are able to develop more integrated and effective support strategies. For this, we use the term holistic problem orientation to indicate the practitioners' openness towards the full extent of residents' problems and opportunities, and the willingness to bend the system of public services delivery in such a way that it matches these problems and opportunities. As a result, not only the exemplary professional's problem orientation but also his or her interventionist actions can be seen as more generalist rather than specialized. What exemplary practitioners have in common is their attention to everyday life, their holistic problem orientation and their commitment to find matching solutions.

\section{Freedom of Mind and Mandate}

Our portrayed exemplary urban practitioners also displayed characteristics that do not easily connect to the entrepreneurship and social engagement dimensions. These practitioners also had considerable freedom of 'mind and mandate'. Freedom of mind translates into the ability to think creatively and to find 'out of the box' solutions; you could call this content creativity. Creativity also refers to the strategic creativity to match generic rules with specific situations. In order to find solutions, the urban practitioner has to deal with institutional, domain or professional rules and boundaries. Exemplary urban practitioners are critical about 'main stream' system urban renewal practices and try to find solutions that start from the lifeworld perspectives of citizens. To achieve this, rules sometimes need to be emphasised and defended, sometimes bend or even ignored.

The exemplary urban practitioners featuring in this study were generally given a certain kind of policy freedom by the institutions they represented in the policy network. In addition to this broad mandate, the practitioners displayed high levels of autonomy and sometimes even a kind of obstinacy that went above and beyond their brief. They do not dogmatically follow the rules, procedures and rationality of their organisation. Exemplary professionals are driven by 'everyday world' logic. This freedom is largely based on their track record and experience. Because of this, they have more opportunities to follow their personal and professional knowledge and 
judgment. It is for this reason that their exemplarity is not something that can be easily copied.

Exemplary urban practitioners are able to make 'local government more open and sensitive to all clients than had traditionally been the case' (Healey 1992, p. 19). By doing so practitioners can help bridge the divide between the lifeworld of communities and the system world of institutions and bureaucracies. Exemplary urban practitioners can act as a catalyst of social change, even if their actions are 'only the first of one of many steps needed' (Waddock and Post 1991, p. 395). The working methods of exemplary practitioners show a mix of entrepreneurialism, strategic networking, empathic engagement and focus on results that differ from standard bureaucracy, but fit very well with what is needed in disadvantaged neighbourhoods.

Our findings demonstrate why filling the void between system and lifeworld is so important given the current government agendas in the UK and the Netherlands. In the post-crisis 'participation society' budgets are being cut and citizens and practitioners are left to work without grants and other forms of support. Exemplary urban practitioners are needed to muster the resources still available; recourses often fragmented across system and lifeworld actors. Institutions such as local authorities and housing associations would act wisely if they treasured and supported exemplary practitioners, in and outside their organisations, and increased their understanding of the diverse character traits and contexts in which exemplary urban practitioners flourish. Some exemplary urban practitioners are successful in their work in the rough-and-tumble of the world outside the bureaucratic institutions; others are more successful inside these institutions. Exemplary urban practitioners can be exemplary because they make a fit with the environment in which they operate. Therefore, the success of exemplary urban practitioners is not just a matter of survival of the fittest, but also one of survival of the fitting.

Open Access This article is distributed under the terms of the Creative Commons Attribution 4.0 International License (http://creativecommons.org/licenses/by/4.0/), which permits unrestricted use, distribution, and reproduction in any medium, provided you give appropriate credit to the original author(s) and the source, provide a link to the Creative Commons license, and indicate if changes were made.

\section{References}

Allen, C. (2008). Housing market renewal and social class. London: Routlegde.

Bang, H. P. (2005). Among everyday makers and expert citizens. In J. Newman (Ed.), Remaking governance: People, politics and the public sphere (pp. 159-178). Bristol: Policy Press.

Bang, H. P., \& Sørensen, E. (1999). The everyday maker: a new challenge to democratic governance. Administrative Theory \& Praxis, 21, 325-341.

Blond, Ph. (2010). Red Tory: How left and right have broken Britain and how we can fix it. London: Faber \& Faber.

Brink, G. V. D., Verhulst, M., de Graaf, L., \& Pennen, T. V. D. (2012). Best Persons; en hun betekenis voor de Nederlandse achterstandswijk [Best Persons and their relevance for deprived neighbourhoods in the Netherlands]. Den Haag: Boom/Lemma.

Clark, B. Y., Brudney, J. L., \& Jang, S. G. (2013). Coproduction of Government Services and the New Information Technology: Investigating the distributional biases. Public Administration Review, 73(5), 687-701. 
Commission, Audit. (2011). Housing Market Renewal Programme review. London: Audit Commission. Communities and Local Government (CLG). (2012). The New deal for communities national evaluation (Vol. 1-7). London: CLG.

Dekker, P., \& Everts, A. (2009). Civicness and the Third Sector: Introduction. VOLUNTAS: International Journal of Voluntary and Nonprofit Organizations, 20, 217-219.

Dunston, R., Lee, A., Boud, D., Brodie, P., \& Chiarella, M. (2009). Co-production and health system reform - re-imagining to re-making. Australian Journal of Public Administration, 68, 39-52.

Durose, C. (2007). Beyond 'street level bureaucrats': Re-interpreting the role of front line public sector workers. Critical Policy Analysis, 1(2), 217-234.

Durose, C. (2009). Front line workers and 'local knowledge': Neighbourhood stories in contemporary UK local governance. Public Administration, 87(1), 35-49.

Durose, C. (2011). Revisiting Lipsky: Front-line work in UK local governance. Political Studies, 59, 978-995.

Forester, J. (1999). The deliberative practitioner: encouraging participatory planning processes. Cambridge (MA); London: The MIT Press.

Habermas, J. (1981). Theorie des kommunikativen Handelns (Vol. 2). Frankfurt am Main: Suhrkamp.

Haffmans, J. (2006). Vrijplaats: hangplek voor vrije gedachten [Refuge: hangout for freethinkers]. Filosofie in bedrijf [Philosophy in Practice], 17(2).

Healey, P. (1992). Planning through debate. The communicative turn in planning theory. Town Planning Review, 632, 143-162.

Hekking, S., Lindemann, S., \& Meier, A. (Eds.) (2010). Optrek in Transvaal. Over de rol van publieke kunst in de stedelijke ontwikkeling. [The Transvaal 'Optrek' project. On the role of public art in urban development] Heijningen: Jap Sam Books.

Hendriks, F., \& Tops, P. (2005). Everyday fixers as local heroes: A case study of vital interaction in urban governance. Local Government Studies, 31, 475-490.

Kingdon, J. (1984/1995). Agendas, alternatives, and public policies. New York: Longman.

Korosec, R., \& Berman E. V. (2006). Municipal support for social entrepreneurship. Public Administration Review, 66(3), 448-462.

Leadbeater, C., \& Goss, S. (1998). Civic entrepreneurship. London: DEMOS.

Leather, P., Nevin, B., Cole, I., \& Eadson, W. (2012). The Housing Market Renewal Programme in England: development, impact and legacy. Sheffield: CRESR Sheffield Hallam University.

Lindemann, S., \& Schutten, S., (Eds.) (2010). Stedelijke transformatie in de stedelijke tussentijd. Hotel Transvaal als impuls voor de wijk. [Urban transformation in the urban interim, The Transvaal Hotel as a catalyst for the area] Amsterdam: SUN Trancity.

Lipsky, M. (1980). Street-level bureaucracy. Dilemmas of the individual in public services (2nd ed.). New York: Russell Sage Foundation.

Lub, V. (2013). Schoon, heel en werkzaam? Een wetenschappelijke beoordeling van sociale interventies op het terrein van buurtleefbaarheid' [Clean, whole and effective? A scientific assessment of social interventions in the domain of neighbourhood liveability]. Den Haag: Boom-Lemma.

Maynard-Moody, S., \& Musheno, M. (2003). Cops, teachers, counselors: Stories from the front lines of public service. Michigan: University of Michigan Press.

Ministry of Housing, Neighbourhoods and Integration. (2007). Actieplan Krachtwijken [Action plan Empowered Neighbourhoods]. Den Haag: WWI.

Mintrom, M., \& Norman, P. (2009). Policy entrepreneurship and policy change. The policy studies journal, 37(4), 649-667.

Morgan, D. (2008). Snowball sampling lemma. The SAGE encyclopedia of qualitative research methods (pp. 816-817). Thousand Oaks: SAGE Publications, Inc.

Mullins, D., \& Van Bortel, G. (2010). Neighbourhood regeneration and place leadership: lessons from Groningen and Birmingham. Policy Studies Journal, 31(4), 413-428.

Osborne, S. (2010a). Delivering public services: Time for a new theory? Public Management Review, 12(1), 1-10.

Osborne, S. (Ed.). (2010b). The New Public Governance, Emerging perspectives on the theory and practice of Public Governance. New York: Routledge.

Osborne, S., Radnor, Z., \& Nasi, G. (2013). A new theory for public service management? Towards a (public) service dominant approach. American Review of Public Administration, 43(2), 135-158.

Pestoff, V. (2014). Collective action and the sustainability of Co-production. Public Management Review, 16(3), 383-401.

Schön, D. (1983). The reflective practitioner. New York: Basic Books. 
Schön, D. (1987). Educating the reflective practitioner. San Francisco: Jossey-Bass.

SCP. (2013). Werken aan de Wijk [Improving neighbourhoods]. The Hague: The Netherlands Institute for Social Research.

Sieckelinck, S., Van Buuren, H., \& Madkouri, E. L. (Eds.). (2013). Onbevoegd Gezag [Unmandated authority]. Den Haag: Boom Lemma.

Steadman, H. (1992). 'Boundary spanners. A key component for the effective interactions of the Justice and Mental Health Care Systems. Law and Human Behavior, 16(1), 75-87.

Stienen, P. (2015). Terug naar de Donderberg [Back to 'Donderberg']. Amsterdam: Nieuw Amsterdam.

Thomas, J. (2012). Citizen, customer, partner: Engaging the public in public management. Armonk, NY: M.E. Sharp.

Tonkens, E. (2014). Participatiesamenleving inhumaan? [Participation Society inhumane?], Socrateslezing, 2 November 2014. Humanistisch Verbond.

Tonkens, E. \& De Wilde, M. (2013). Als meedoen pijn doet [When participation hurts]. Amsterdam: Amsterdam Institute for Social Science Research (AISSR).

Tops, P., \& Hartman, C. (2009). The relation between policy governance and front-line governance. In W. Duyvendak, F. Hendriks, \& M. van Niekerk (Eds.), City in sight. Dutch dealings with urban change (pp. 191-201). Amsterdam/The Hague: Amsterdam University Press/Nicis Institute.

Van Bortel, G. (2009). Network governance in action: The case of Groningen; complex decision-making in urban regeneration. Journal of Housing and the Built Environment, 24, 167-183.

Van Bortel, G. (2013). A tale of two cities. Paper written for the 2013 ENHR conference in Tarragona Spain.

Van Bortel, G., \& Mullins, D. (2009). Critical perspectives on network governance in urban regeneration, community involvement and integration. Journal of Housing and the Built Environment, 24, 203-219.

Van Bortel, G., Mullins, D., \& Rhodes, M.-L. (2009). Exploring network governance in urban regeneration, community involvement and integration. Journal of Housing and the Built Environment, 24, 93-101.

Van den Brink, G., van hulst, M., de Graaf, L., \& Pennen, T. V. D. (2012). Best persons, en hun betekenis voor de Nederlandse achterstandswijk. [Best persons, and their significance for Dutch deprived neighbourhoods]. Den Haag: Uitgeverij Boom Lemma.

Van der Lans, J. (2012). Loslaten, Vertrouwen en Verbinden, over Burgers en Binding [Release, Trust and Connect, on Citizens and Cohesion]. Stichting Doen.

Van der Pennen, T. (2014). The Fourth Way of Active Citizenship. In N. Gallent \& D. Ciaffi (Eds.), Community action and planning. Bristol: Policy Press.

Van Hulst, M., De Graaf, L., \& Van den Brink, G. (2011). Exemplary practitioners: A review of actors who make a difference in governing. Administrative theory \& praxis, 33(1), 120-142.

Van Hulst, M., De Graaf, L., \& Van den Brink, G. (2012). The work of exemplary practitioners in neighborhood governance. Critical Policy Studies, 6(4), 434-451.

Van Kempen, R. (2000). Big cities policy in the Netherlands. Tijdschrift voor Economische en Sociale Geografie., 91, 197-203.

Van de Wijdeven, T. M. F., \& Hendriks, F. (2009). A little less conversation, a little more action: real-life expressions of vital citizenship in city neighbourhoods. In J. W. Duyvendak, F. Hendriks, \& M. van Niekerk (Eds.), City in sight. Dutch dealings with urban change (pp. 121-140). Amsterdam/The Hague: Amsterdam University Press/Nicis Institute.

Vogelaar, E. (2007). Actieplan Krachtwijken [Action Programme Empowered Neighbourhoods]. Den Haag: Department for Housing, Neighbourhoods and Integration.

VROMRaad. (2007). Stad en Stijging [The city and upward social mobility]. Den Haag: VROMRaad.

Waddock, S. A., \& Post, J. E. (1991). Social entrepreneurs and catalytic change. Public Administration Review, 51(5), 393-401.

Webb, D. (2010). Rethinking the role of markets in urban renewal: The housing market renewal initiative in England. Housing, Theory and Society, 27(4), 313-331.

Weber, M. (1922). Grundriss der Socialokonomik. Tubingen: Verlag J. Mohr.

Wetenschappelijke Raad voor het Regeringsbeleid (WRR). (2012). Vertrouwen in de Burger [Trust in the Citizens]. SDU: Den Haag.

Williams, P. (2002). The competent boundary spanner. Public Administration, 80, 103-124.

Wilson, W. (2013). Housing market renewal pathfinders. London: House of Commons Library. 